\title{
Lake Van Drilling Project: A Long Continental Record in Eastern Turkey
}

\author{
by Thomas Litt, Sebastian Krastel, Sefer Örçen, and Mustafa Karabiyikoglu
}

doi:10.2204/iodp.sd.4.13.2007

An international research group is proposing a new research initiative, the Lake Van Drilling Project 'PaleoVan' within the framework of the International Continental Scientific Drilling Program (ICDP). The project mainly aims at obtaining high-resolution paleoclimate records from lacustrine sediments, where biotic and abiotic parameters provide proxy climate data. Lake Van in Turkey has the potential to yield long continental records covering several glacial-interglacial cycles from annually-laminated sediments, hence making the lake a key site for the investigation of the Quaternary climate evolution in the Near East.

To exploit this potential, an ICDP workshop was held in Van, Turkey on 6-9 June 2006, organized by the Institute of Paleontology, University of Bonn (Germany), and hosted by the University of Van (Turkey), with funding from the ICDP. Thirty-five researchers from twelve countries took part in the meeting, including representatives of the ICDP and Drilling, Observation and Sampling of the Earths Continental Crust (DOSECC). The workshop reviewed existing data and set priorities for an ICDP drilling proposal to obtain deep cores from the lake.

Lake Van is on a high plateau in eastern Anatolia (Fig. 1). Extending for $130 \mathrm{~km}$ WSW-ENE, it has a surface area of $3500 \mathrm{~km}^{2}$, a volume of $580 \mathrm{~km}^{3}$, and a maximum depth of $450 \mathrm{~m}$. The present lake level is $1650 \mathrm{~m}$ above sea level. The climate of the area is continental, with hot and dry summers and cold winters. The Lake Van drainage basin covers $16,000 \mathrm{~km}^{2}$ and lies within the eastern part of the larger Muş Basin. Lake Van water is highly alkaline with a $\mathrm{pH}$ of up to 9.8. Salinity is $22 \%$, and the calcium concentration is only $4 \mathrm{mg} \mathrm{L}^{-1}$ (Landmann et al. 1996). The southern shore is

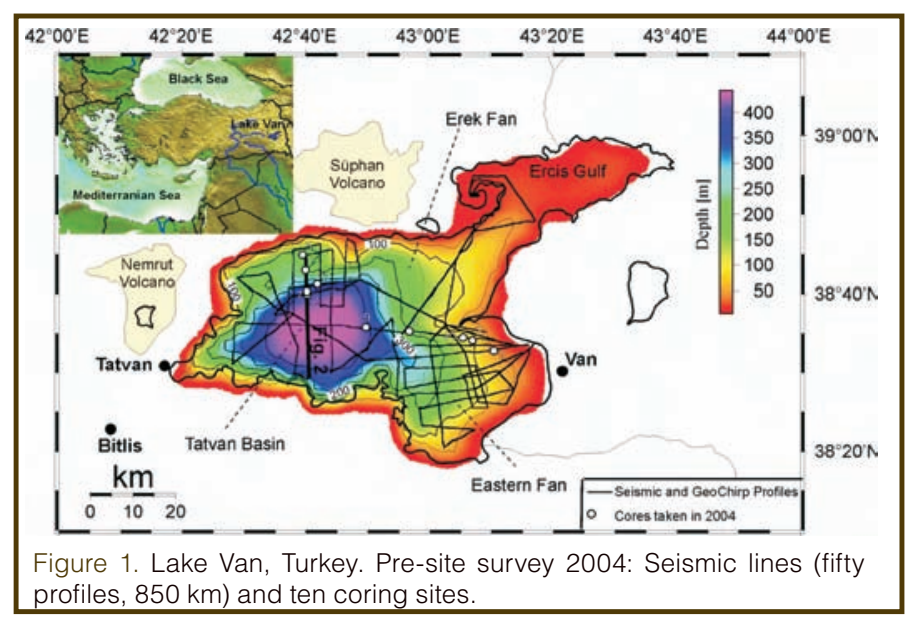

formed by the Bitlis massif (3500 $\mathrm{m}$ above sea level), and the areas north and west of the lake are dominated by the large volcanoes Nemrut and Süphan. Lavas and/or pyroclastic flows sourced in the Nemrut volcano may have built the dam that now separates Lake Van from the rest of the Muş Basin. Rivers within the Lake Van basin discharge water and sediment into the lake, which has no outflow today. Lake Van is the fourth-largest terminal lake in the world and is long known as a very active seismic zone. About thirty earthquakes with magnitude $\geq 5.0$ have occurred in the vicinity of Lake Van since 1900.

Interpretations of existing datasets obtained during the last decades were presented at the workshop. Shallow sediment cores provided evidence of an annually-laminated varve sequence. High resolution hydrochemical, geochemical, geological, and biological investigations of Lake Van in the seventies (Kempe \& Degens, 1978) were continued in 1990 during a German-Swiss expedition (EAWAG Zürich, Switzerland; University Hamburg, Germany) (Landmann et al., 1996; Wick et al., 2003). Initial reconstruction of the frequency, duration, and rate of climate change in eastern Anatolia during the last 12,500 years is based on varve counting in these cores. Continuous records of varve thickness, geochemistry, stable isotopes, and pollen indicate several different climate phases (Wick et al., 2003). At least eleven volcanic ash layers have been described in these records (Landmann et al., 1996).

So far, however, it has only been possible to core to depths down to $10 \mathrm{~m}$ below the lake bottom, recovering Weichselian late glacial and Holocene material. Therefore, the ICDP focus program funded by the German Research Foundation financed a geophysical survey in combination with a coring campaign to prepare for a deeper lake drilling. The geophysical survey was carried out in June 2004. Fifty seismic profiles were collected, with a total length of $\sim 850 \mathrm{~km}$ (Fig. 1). The new seismic net covers most of the lake and clearly proves the possibility to recover long continuous cores from Lake Van. Based on the seismic results, ten different locations in water depth up to $420 \mathrm{~m}$ were cored (24 July to 10 August 2004) to a maximum depth of $10 \mathrm{~m}$ below the lake floor. A specially designed deep-water piston corer was used to obtain cores longer than those obtained by the previously deployed Kullenberg piston corer system. Successful operation in water depths as deep as $400 \mathrm{~m}$ was a milestone in testing this new coring system. In addition, a Kullenberg 
piston corer was used to recover a set of multiple cores along the seismic lines. Short cores of the uppermost $1.5 \mathrm{~m}$ were taken at all drilling locations by a gravity corer to obtain undisturbed samples of the uppermost soft, water-rich sediments.

The initial results of the geophysical processing and multidisciplinary scientific work on the new cores, including magnetic susceptibility, physical properties, stable isotopes, XRF scans, and pollen and spores analyses, were also presented during the workshop. The drilling site of one of the new cores, VAN04-2 (375 m water depth), was identified as a potential ICDP drilling site in the seismic data, as it reaches deeper in time than all Lake Van cores obtained before (Figs. 2 and 3), probably spanning the last 20,000 years. There is no evidence of aragonite crusts or similar layers that would indicate extreme low stands in this part of the basin between the last glacial maximum and the present as proposed by some researchers. The laminated record appears to be one of continuous sedimentation. Seismic records suggest that at this water depth, long continuous records of up to $500 \mathrm{ka}$ should be present (Fig. 2).

Specific goals as determined by the workshop will be to reconstruct the following: (1) paleoclimate in a sensitive semiarid region based on transfer functions for pollen, and stable isotopes as well as modeling; (2) climate variability in space and time based on teleconnection with other high-resolution records such as ice cores and marine sequences; (3) dynamics of lake level fluctuations and hydrogeological development; (4) formation and age of Lake Van; (5) history of volcanism and volcanic activities based on tephrostratigraphy; (6) variations of the earthmagnetic field; (7) tectonic, paleoseismic, and earthquake activities; and (8) interactions between man and environment since prehistoric times. An ICDP drilling proposal addressing these topics at Lake Van will be submitted to the ICDP in 2007.

\section{References}

Kempe, S., and Degens, E.T., 1978. Lake Van varve record: the past 10,420 years. In Degens, E.T., and Kurtman, F. (Eds.), The Geology of Lake Van: The Mineral Research and Exploration Institute of Turkey, Ankara pp.56-63 (MTA Press).

Landmann, G., Reimer, A., Lemcke, G., and Kempe, S., 1996. Dating Late Glacial abrupt climate changes in the 14,570 yr long continuous varve record of Lake Van, Turkey. Palaeogeogr., Palaeoclimatol., Palaeoecol., 122:107-118.

Wick, L., Lemcke, G., and Sturm, M. 2003. Evidence of Late-Glacial and Holocene climatic change and human impact in eastern Anatolia: high-resolution pollen, charcoal, isotopic and geochemical records from the laminated sediments of Lake Van, Turkey. Holocene, 13:665-675.

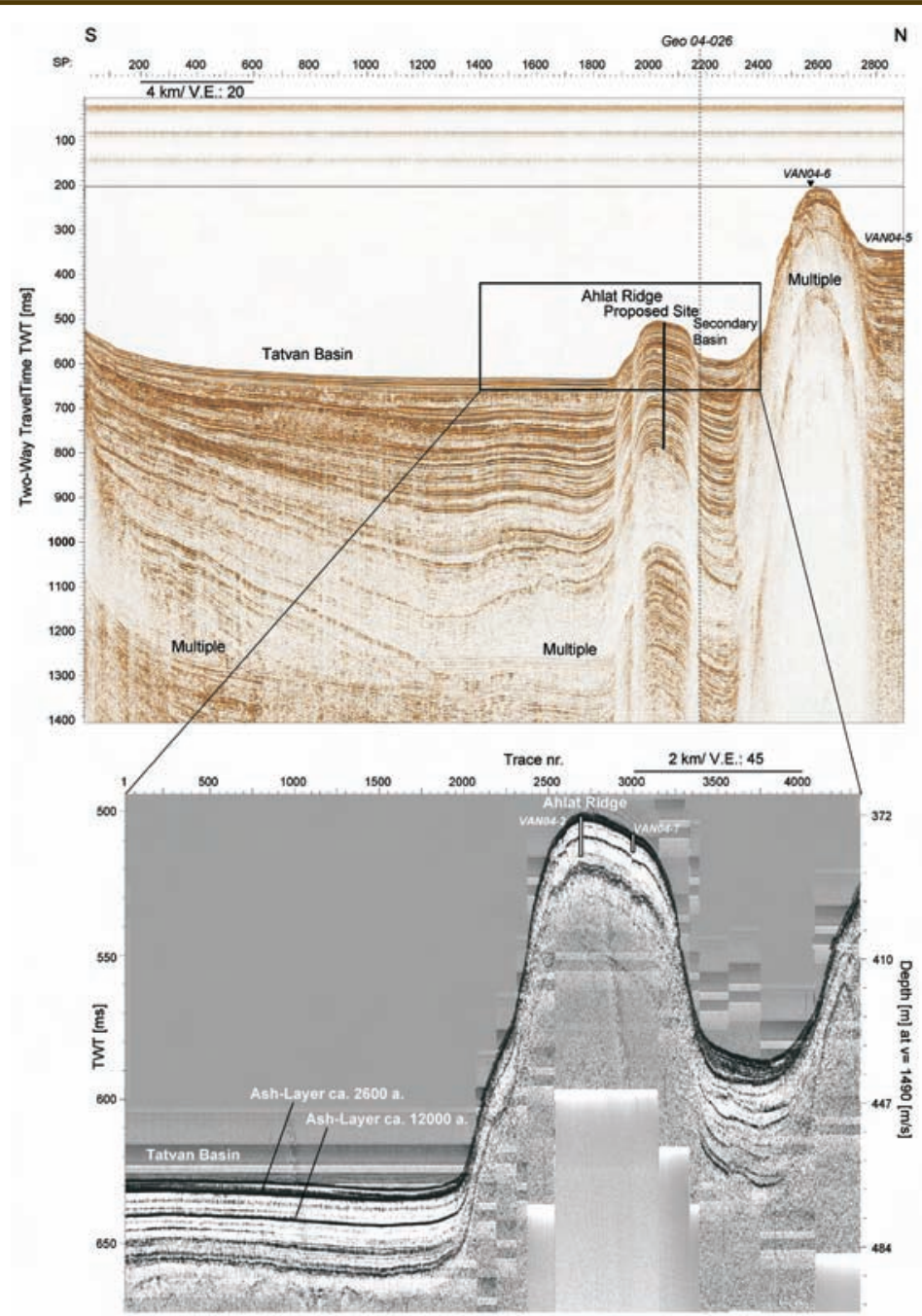

Figure 2. Stack (top) and part of Geochirp Profile GeoB04-007 (bottom) across the Tat-Van Basin. The ages for the ash layers are taken from Landmann et al. (1996). See Fig. 1 for location of the profile and Fig. 3 for sediment core VAN04-02.

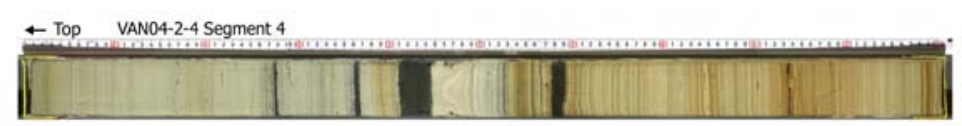

Figure 3. Core photo from core Site 2 obtained in 2004 (VAN04-2-4, segment 4) with annually laminated lacustrine sediments and intercalated tephra layers.

\section{Authors}

Thomas Litt, Institute of Paleontology, University of Bonn, Nussallee 8, 53115 Bonn, Germany, e-mail: t.litt@uni-bonn. de

Sebastian Krastel, Faculty of Geosciences, University of Bremen, Klagenfurter Straße, 28359 Bremen, Germany

Sefer Örçen, Department of Geology, Yuzuncu Y1 Universitesi, Zeve Kampusu, 65080 Van, Turkey

Mustafa Karabiyikoglu, Department of Anthropology, Yuzuncu Y1 Universitesi, Zeve Kampusu, 65080 Van, Turkey

\section{Related Web Link}

http://van.icdp-online.org 